\title{
A novel strategy for processing, production and quality control of an iron-free nutraceutical supplement that rapidly restores iron-dependent hemoglobin in red blood cells
}

\author{
Debasis Bagchi ${ }^{1,2^{*}}$, Bernard W. Downs ${ }^{1}$, Manashi Bagchi ${ }^{3}$ and Steve Kushner ${ }^{4}$
}

\begin{abstract}
We hypothesize that Iron-Deficiency Anemia (IDA) has been misconceptualized. In the body, low blood iron is not caused by a deficiency. The primary cause of low iron, appearing to be IDA, is the expenditure of alkalinizing histidine, from heme protein, which requires the cleavage of iron and its repartitioning to other storage depots. As an alkaline buffer, histidine is released to counterbalance the increase in an anaerobic hypoxic (i.e. increased acidic) blood $\mathrm{pH}$, thereby maintaining a $\mathrm{pH}$ of 7.4. Our research team coined the more accurate term for this pathogenic condition, "Chronic Anemia Syndrome" (CAS).
\end{abstract}

Keywords: Anemia, A multi-nutrient nutraceutical, VMP35, Hematology, Hemoglobin

The National Heart, Lung, and Blood Institute (NHLBI) reported that anemia is the most common blood disorder worldwide and is greatly associated with diverse chronic inflammatory conditions including chronic kidney disease, gastrointestinal and gynecological malignancies, and autoimmune distress (Kassebaum 2016). The Global Burden of Disease 2016 (GBD 2016) disclosed that iron-deficiency is the leading cause of anemia, which globally afflicts 1.93 billion people (Kassebaum 2016; Iron deficiency anemia 2018). Again, substantial loss of blood may occur due to an accident inducing hemorrhagic anemia leading to dramatic alterations in the hematological parameters and blood chemistry, reducing iron levels in the blood (Iron deficiency anemia 2018).

\footnotetext{
* Correspondence: debasisbagchi@gmail.com

'VNI Inc., Lederach, PA, USA

${ }^{2}$ Texas Southern University, College of Pharmacy and Health Sciences, Houston, TX, USA

Full list of author information is available at the end of the article
}

Occurrence of anemia is greatly associated with low iron function in available transferrin, the glycoproteins that bind to and consequently mediate iron transportation through blood plasma for normal physiological functions (Iron deficiency anemia 2018; Corbier et al. 2019). Three main storage tissues for ferritin iron are gut, macrophages, and hepatic tissues. In addition to a loss of heme iron, iron storage declines or is lost dramatically in these 3 tissue compartments during anemia (Iron deficiency anemia 2018; Corbier et al. 2019). Oxygen availability as well as the availability of iron greatly decline during a hemorrhage, which leads to anemia and fatigue (Corbier et al. 2019).

There are believed to be five major causes of anemia (Iron deficiency anemia 2018):

(i) Loss of blood due to excessive menstrual bleeding; or bleeding in the digestive or urinary tract, surgery, trauma, and cancer,

(c) The Author(s). 2020 Open Access This article is licensed under a Creative Commons Attribution 4.0 International License, which permits use, sharing, adaptation, distribution and reproduction in any medium or format, as long as you give appropriate credit to the original author(s) and the source, provide a link to the Creative Commons licence, and indicate if changes were made. The images or other third party material in this article are included in the article's Creative Commons licence, unless indicated otherwise in a credit line to the material. If material is not included in the article's Creative Commons licence and your intended use is not permitted by statutory regulation or exceeds the permitted use, you will need to obtain permission directly from the copyright holder. To view a copy of this licence, visit http://creativecommons.org/licenses/by/4.0/ 
(ii) Hemorrhagic anemia due to substantial loss of blood leading to significant alterations in blood parameters including reduced iron,

(iii) Nutritional deficiencies of iron and a consequential inability to generate healthy hemoglobin and therefore an inability to regenerate red blood cells,

(iv) Hereditary reasons of compromised conditions of red blood cell production such as Thalassemia, and

(v) Chemotherapy or radiation therapy.

The literature reveals that four major iron-containing proteins exist in a human body, namely (i) mononuclear proteins, (ii) diiron-carboxylate proteins, (iii) iron-sulfur proteins and (iv) heme proteins. Of these, the most abundant iron containing proteins in the human body are heme proteins. Hemoglobin, located in erythrocytes or red blood cells, contains approximately $50 \%$ of the total body iron and plays a central role in preventing anemia. Erythropoiesis, the production of erythrocytes, is regulated by three major factors (a) appropriate oxygenation of tissues and organs, (b) erythrocyte turnover, and (c) loss of erythrocytes due to hemorrhage (Iron deficiency anemia 2018; Corbier et al. 2019).

It has been demonstrated that erythrocytes and their precursors, erythroblasts, require a requisite amount of functional iron and oxygen for the manufacturing of hemoglobin and heme. Iron is centrally located in the hemoglobin structure and is essential for the important functions of hemoglobin (Iron deficiency anemia 2018; Corbier et al. 2019). Basically, erythroblasts, the precursors of erythrocytes, are nucleated cells that exist in the bone marrow. Plasma contains a considerable amount of mono- and di-ferric transferrin, which are the primary sources of functional iron for erythroblasts (Iron deficiency anemia 2018; Corbier et al. 2019).

Anemia can now be recognized as an etiological antecedent, a primary underlying cause to all the chronic anaerobic pathologies and disorders (Corbier et al. 2019). Our research team coined a term, Chronic anemia syndrome (CAS), which covers all other forms of irondeficiency anemia (IDA) and anemia of chronic disease (ACD), except those due to genetic or hemorrhagic conditions (Corbier et al. 2019; Downs et al. 2020). This encompasses a constellation of chronic inflammatory conditions resulting from an increase in the anaerobic/ acidic environment, which in turn fosters the growth of pathogenic anaerobic organisms (Corbier et al. 2019). Alternatively, CAS is represented by an expenditure of primary intracellular alkalinizing ion buffers leading to a defensive expenditure of secondary alkaline buffers, primarily histidine from heme protein, to inhibit a remarkable lowering of blood $\mathrm{pH}$. It is well established that four histidine molecules are attached to a heme group, with an iron atom in the center of the protoporphyrin ring. The iron atom in the heme protein binds to four nitrogen atoms of the histidine molecules (Corbier et al. 2019). During anemia, iron is cleaved from the hemeligating proteins to release histidine. In turn, iron is removed from circulation, repartitioned and reserved in the hepatic storage reservoirs and other tissues. An excessive accumulation of iron in the organs can lead to a state of hemochromatosis. This pathophysiological condition is termed "iron overload anemia". Under the conditions of more severe hemochromatosis, massive downregulation, or cessation of iron deposition occurs in those organs leading to an excessive accumulation of unbound iron in the blood plasma. Accordingly, the restoration of hemoglobin $(\mathrm{Hb})$ status in red blood cells (RBCs) gets perturbed due to an excess expenditure of histidine from heme proteins to preserve an ideal alkaline blood $\mathrm{pH}$ and oxygen exertion (Corbier et al. 2019). The terminology 'chronic anemia syndrome (CAS)' demonstrates the progressive inability of the human body to effectively use cellular oxygen, which causes progressive acidemia in the blood supply as evidenced by an increasing hypochromic state of the RBCs due to a significant loss of $\mathrm{Hb}$. This induces a metabolic shift toward cellular anaerobic glycolysis, and a further compensatory expenditure of alkalinizing histidine molecules from the heme protein of deconjugated $\mathrm{Hb}$, which releases even more iron (Corbier et al. 2019; Downs et al. 2020; Blum et al. 2020). The iron-free VMP35 MultiNutrient Nutraceutical supplement technology was was developed and clinical research and case studies on its effect on anemia and other blood properties were evaluated (Corbier et al. 2019; Downs et al. 2020; Blum et al. 2020).

\section{Conclusion}

Our hypothesis, supported by clinical research revelations, is that Iron Deficiency Anemia (IDA) has been misconceptualized. The low level of iron in the blood is not caused by a deficiency or loss of iron in the body. The primary cause of low iron, appearing to be IDA, is the expenditure of histidine, an alkalinizing amino acid, from heme protein, which requires the cleavage of iron and its repartitioning to other storage depots. As an alkaline buffer, histidine is released to counterbalance the increase in an anaerobic hypoxic (i.e. increased acidic) $\mathrm{pH}$ in the blood, thereby maintaining a $\mathrm{pH}$ of 7.4. Our research team has coined the more accurate term for this pathogenic condition, "Chronic Anemia Syndrome" (CAS).

\section{Abbreviations}

CAS: Chronic anemia syndrome; IDA: Iron-deficiency anemia; ACD: Anemia of chronic disease; Hb: Hemoglobin; RBCs: Red blood cells; LBCl: Live blood cell imaging 


\section{Acknowledgements}

Not applicable.

\section{Authors' contributions}

All authors contributed equally to the manuscript. All authors read and approved the manuscript.

\section{Funding}

Not applicable.

\section{Availability of data and materials}

Not applicable.

\section{Competing interests}

The authors are associated with VNI Inc., Lederach, PA.

\section{Author details}

'VNI Inc., Lederach, PA, USA. ${ }^{2}$ Texas Southern University, College of Pharmacy and Health Sciences, Houston, TX, USA. ${ }^{3}$ Dr. Herbs LLC, Concord, CA, USA.

${ }^{4}$ ALM R\&D, Oldsmar, FL, USA.

Received: 9 November 2020 Accepted: 12 November 2020

Published online: 23 November 2020

\section{References}

Blum, K., Downs, B. W., Bagchi, M., Kushner, S., Morrison, B. S., Galvin, J., ... Bagchi, D. (2020). Induction of homeostatic biological parameters in reward deficiency as a function of an iron-free multinutrient complex: promoting hemoglobinization, aerobic metabolism, viral immuno-competence, and neuroinflammatory regulation. Journal of Systems and Integrative Neuroscience, 7, 1-15. https://doi.org/10.15761/JSIN.1000234.

Corbier, J. R., Downs, B. W., Kushner, S., Aloisio, T., Bagchi, D., \& Bagchi, M. (2019). VMP35 MNC, a novel iron-free supplement, enhances cytoprotection against anemia in human subjects: a novel hypothesis. Food \& Nutrition Research, 63, 3410. https://doi.org/10.29219/fnr.v63.3410.

Downs, B. W., Corbier, J. R., Speight, N., Kushner, S., Aloisio, T., Bagchi, M., \& Bagchi, D. (2020). Anemia: influence of dietary fat, sugar, and salt on hemoglobin and blood health. In H. G. Preuss, \& D. Bagchi (Eds.), Dietary sugar, salt, and fat in human health, (pp. 103-128). Amsterdam: Elsevier/ Academic Press.

Iron deficiency anemia. Available from: https://www.mayoclinic.org/diseasesconditions/iron-deficiency-anemia/symptoms-causes/syc-20355034 [cited 16 Dec 2018].

Kassebaum, N. J. (2016). The global burden of anemia. Hematology/Oncology Clinics of North America, 30(2), 247-308. https:/doi.org/10.1016/j.hoc.2015.11.002.

\section{Publisher's Note}

Springer Nature remains neutral with regard to jurisdictional claims in published maps and institutional affiliations. 